\title{
Makna Kewirausahaan Pada Etnis Melayu, Etnis Jawa, Etnis Tionghoa, dan Etnis India di Kota Medan
}

\section{The Meaning of Entrepreneurship in Malay Ethnics, Javanese, Chinese and Indian in Medan City}

\author{
Rianda Elvinawanty(1), Lydia Yusnita(2)*, Veronica Rania(3), Lusiati br Silaban(4) \& \\ Widya Christiani Sembiring(5) \\ Fakultas Psikologi, Universitas Prima Indonesia, Indonesia
}

Disubmit: 22 September 2020; Diproses: 23 September 2020; Diaccept: 07 November 2020; Dipublish: 01 Desember 2020 *Corresponding author: E-mail: tjiayu88@gmail.com

\begin{abstract}
Abstrak
Setiap wirausahawan pasti memiliki kearifan lokal masing-masing dalam membangun usaha. Pada setiap etnis dapat dibedakan dari budaya yang dikaitkan dalam membangun usaha. Penelitian ini bertujuan untuk menjelaskan makna kewirausahaan pada empat etnis yang berbeda, yakni Melayu, Jawa, Tionghoa, dan India dikota Medan. Penelitian ini menggunakan metode kualitatif serta teknik pengambilan sampel menggunakan teknik purposive sampling. Dalam memperoleh data digunakan metode wawancara dan observasi. Alasan peneliti dalam menggunakan teknik penelitian ini adalah ingin menggali lebih dalam makna kewirusahaan pada setiap etnis yang berbeda. Hasil yang ditemukan dalam penelitian ini pada Melayu terdapat mental berwirausaha yang sudah menjadi bakat, gaya hidup yang optimis, toleran, serta tetap berpegang pada adat istiadat dimana adanya sopan santun, ramah, demokratis serta mengutamakan diplomasi daripada kekerasan. Pada etnis Jawa adalah memiliki etos kerja yang kuat, memprioritaskan keakraban, menghindari konflik, menerima segala sesuatu dengan tulus, dan juga memberi upaya maksimal dalam melakukan pekerjaan. Pada etnis Tionghoa juga ditemukan adanya perhatian, fokus dapat dipercaya, kerja keras, berhemat, solidaritas keluarga, pendidikan, dan kebajikan atau moral etika dalam berwirausaha, kestabilan emosi, ketelitian, keberanian, serta kejujuran. Serta pada etnis India terdapat motivasi berprestasi, dan taat menjalankan upacara-upacara sebagai permintaan doa demi kesuksesan usaha.
\end{abstract}

Kata kunci: Etnis Melayu; Etnis Jawa; Etnis Tionghoa; Etnis India; kewirausahaan; makna kewirausahaan.

\begin{abstract}
Every entrepreneur must have their own local wisdom in building a business. Each ethnic group can be distinguished from the culture associated with building a business. This study aims to explain the meaning of entrepreneurship in four different ethnicities, namely Malay, Javanese, Chinese and Indian in the city of Medan. This study uses qualitative methods and the sampling technique uses purposive sampling technique. In obtaining data used interview and observation methods. The reason the researcher uses this research technique is to want to dig deeper into the meaning of entrepreneurship in each different ethnicity. The results found in this study in Malay are that there is an entrepreneurial mentality that has become a talent, an optimistic, tolerant lifestyle, and sticking to customs where there is courtesy, friendly, democratic and prioritizes diplomacy over violence. The Javanese ethnic group has a strong work ethic, prioritizes intimacy, avoids conflict, accepts everything sincerely, and also gives maximum effort in doing work. The Chinese also found concern, trustworthy focus, hard work, frugality, family solidarity, education, and virtue or moral ethics in entrepreneurship, emotional stability, thoroughness, courage, and honesty. As well as ethnic Indians, there is achievement motivation, and obediently carry out ceremonies as a prayer request for business success.
\end{abstract}

Key words: Ethnic Malay; Javanese; Chinese; Indian; entrepreneurship; the meaning of entrepreneurship.

Rekomendasi mensitasi :

Elvinawanty, R., Yusnita, L., Rania, V., Silaban, L.B., \& Sembiring, W.C., 2020. Makna Kewirausahaan Pada Etnis Melayu, Etnis Jawa, Etnis Tionghoa, dan Etnis India di Kota Medan. Jurnal Penelitian Pendidikan, Psikologi dan Kesehatan (J-P3K), 1(3): 174-181. 


\section{PENDAHULUAN}

Budaya merupakan ciri khas dari suatu kelompok. Hofstede (Tan, 2013) mendefinisikan budaya atau kultur sebagai suatu sistem nilai-nilai kolektif yang membedakan anggota satu kelompok dengan kelompok yang lainnya. Sebagai sebuah bangsa yang multikultural, Bangsa Indonesia mempunyai aneka ragam kearifan lokal. Menurut Martawijaya (2016) kearifan lokal adalah salah satu sumber nilai-nilai karakter individu dalam suatu kelompok. Wujud kearifan lokal yang dianut oleh masyarakat pada suatu daerah atau komunitas dapat berwujud seperti perkataan, tindakan, tulisan serta benda buatan manusia.

Entrepreunership atau kewirausahaan merupakan salah satu wujud dari kearifan lokal dalam bentuk tindakan. Selaras dengan penelitian Sapir, dkk (2014) yang mengatakan bahwa nilai-nilai kerifan lokal dapat menjadi inspirasi untuk pengembangan dalam berwirasausaha. Menurut Soegoto (2010) Enterpreneurship adalah usaha kreatif yang dibangun berdasarkan inovasi untuk menghasilkan sesuatu yang baru, memiliki nilai tambah, memberi manfaat, menciptakan lapangan kerja dan hasilnya berguna bagi orang lain. Dalam berwirausaha tidak akan lepas dari faktor budaya. Dimana faktor budaya juga sangat mempengaruhi tingkat produktivitas, attitude dan cara pandang seseorang sebagai hasil interaksi budaya masyarakat merupakan faktor utama yang menghambat pengembangan. Faktor budaya ini juga senada dengan penelitian yang dilakukan oleh Husni (2017), bahwa budaya merupakan salah satu hal yang melekat dalam mencapai kesuksesan dalam berwirausaha. Kesuksesan dalam berwirausaha cukup dipengaruhi dari budaya suku masing-masing. Seperti Penelitian yang dilakukan oleh Hasbullah dan Jamaluddin (2013) menyatakan bahwa pada etnis Melayu memiliki mental berwirausaha yang sudah menjadi bakat, kemudian lanjut pada penelitian Junaidi (2016), yang menemukan kewirausahaan pada etnis Melayu didasari dari gaya hidup yang optimis, toleran, serta tetap berpegang pada adat istiadat dimana adanya sopan santun, ramah, demokratis serta mengutamakan diplomasi daripada kekerasan. Juga senada dengan penelitian yang dilakukan oleh Anggraini (2017), menyatakan bahwa etnis Melayu memiliki nilai ketekunan dalam menjalankan usaha, memiliki manajemen waktu yang baik, kreatifitas yang tinggi dalam mengembangkan produk dalam usahanya serta memiliki perencanaan yang tepat.

Selain pada etnis Melayu, etnis lainnya juga memiliki keunikan masingmasing dalam berwirausaha. Etnis Jawa juga memiliki kearifan sendiri, seperti penelitian yang dilakukan oleh Andri, dkk (2019), mengatakan bahwa etnis Jawa sendiri memiliki beberapa nilai inti yang terdiri dari etos kerja yang kuat, menghindari konflik, menerima segala sesuatu dengan tulus (yang disebut nrimo atau nrima), memprioritaskan kekerabatan (tuna satak bathi sanak), memandang pekerjaan mereka sebagai cara untuk mendapatkan berkah (laku tirakat), dan juga memberi maksimal upaya dalam melakukan pekerjaan mereka (panggautan gelaring pambudi).

Pada etnis Tionghoa terdapat beberapa sikap dalam berwirausaha, yaitu pada penelitian yang dilakukan oleh Koning (2007), keberhasilan bisnis etnis 
Tionghoa di Indonesia dikaitkan dengan kemandirian dan kuncinya adalah adanya perhatian, fokus dapat dipercaya, kerja keras, berhemat, solidaritas keluarga, pendidikan, dan kebajikan atau moral etika dalam berwirausaha. Sama hal nya dengan penelitan oleh Susanto dan Nurrachman (2018) beberapa sikap yang lebih terlihat pada studi terkait kewirausahaan antara lain kestabilan emosi, ketelitian, keberanian, serta kejujuran pada etnis Tionghoa. Serta penelitian yang dilakukan oleh Tandelilin (2020), menyatakan bahwa etnis Tionghoa memiliki nilai-nilai Konfusianisme yaitu guanxi solidaritas keluarga.

Selain pada etnis Tionghoa, etnis India juga memiliki sikap dalam berwirausaha, pada hasil penelitian yang dilakukan oleh Mariani dan Eliana (2012), pada suku India terdapat nilai-nilai yang dipegang teguh agar mencapai tujuan yang diinginkannya antara lain yaitu motivasi berprestasi. Zulkifli (2005) dalam penelitiannya menyatakan bahwa pada suku India terdapat nilai-nilai yang dipegang teguh agar mencapai kesuksesan, yaitu taat menjalankan upacara-upacara sebagai permintaan doa demi kesuksesan usaha.

Dalam uraian diatas, ada beberapa wawancara yang dilakukan oleh peneliti dengan subjek tentang makna kewirausahaan. Berikut adalah kutipan wawancara yang dilakukan dengan beberapa subjek pada etnis Melayu, etnis Tionghoa dan etnis India.

"ibaratnya kakak ini udah tolong jangan dipentong, tolong menolonglah dalam dagang, ramahnya harus diutamakan, trus jujur. walaupun dia gak ada uang terus terang jujur aja kapan dia bisa bayar, jangan bohong sama aku. hmm.. kayak mana yah.. harus yakin apa yang kita jalani itu.. insyaAllah bisa berhasil, sopan santun harus kita jaga, ramah tamah. Toleransi juga harus ada untuk pembeli, tapi kayak gitu kita jujur pun ada orang nokohin.. kan aku minta nya gini lo, seberapa bisa coba bayar. cuma dia kayaknya memang gak mau bayar kak.. ya udah kita pasrahkan saja dengan yang diata. iya saya memang sudah ada bakat dari kecil."

Berdasarkan pernyataan subjek diatas, dapat dicermati bahwa tujuan dan makna kewirausahaan pada etnis Melayu adalah bertutur kata sopan, adanya sopan santun dalam bersikap, ramah, tolongmenolong, berdoa, optimis, lemah lembut, memiliki sikap toleransi, serta memiliki bakat dari kecil.

"Tapi lama kelamaan karna ada kepercayaan ya dia ambil banyak barang dari saya mau yang murah atau yang mahal. Jadi saya itu harus rajin-rajin untuk menawarkan barang saya ke orang. Dan disini itu harus jujur ya. Kalau pelanggan minta 1 ya kami kasih 1. Kalau minta 2 tapi kami kasih 1 kan bohong itu namanya. Jadi disini itu sama pelanggan harus ada kejujuran dan kepercayaan."

Berdasarkan pernyataan subjek diatas, dapat dicermati bahwa makna kewirausahaan pada etnis Tionghoa adalah dapat dipercaya agar mendapat kepercayaan dari pelanggan, serta bersifat rajin dan jujur.

"Kami pertama ngak ada dana sama sekali, jadi kami dari keuntungan itu kami kumpulin, nabung sedikit demi sedikit, jadi berapa pun hasil keuntungan kami tabung ke bank, jadi lama-lama ngumpul dan bisa 
belanja yang lain, prosesnya 8 tahun baru bisa besar, ini kan ko sewa ni kan, kalo ini udah bisa dujual ya target kita mau buka didaerah lain, karena kita tunggal jual batik disini jadi semangatnya disitu, dulu ngak punya apa-apa sekarang punya uang sendiri, yamateri meningkat."

Berdasarkan pernyataan subjek diatas, dapat dicermati bahwa makna kewirausahaan pada etnis India adalah memiliki motivasi yang tinggi dalam menjalakan usaha.

Berdasarkan fenomena-fenomena yang terjadi di masyarakat yang berkaitan dengan kewirausahaan, maka peneliti tertarik untuk meneliti "Makna Kewirausahaan Pada Etnis Melayu, Etnis Jawa, Etnis Tionghoa, dan Etnis India di Kota Medan"

Penelitian ini diharapkan dapat menjawab pertanyaan penelitian mengenai fenomena yang dikaji oleh peneliti. Adapun pertanyaan yang ingin di jawab peneliti adalah bagaimana makna kewirausahaan yang terdapat pada etnis Melayu, etnis Jawa, etnis Tionghoa dan etnis India?

Tujuan dari penelitian ini adalah untuk mengetahui makna kewirausahaan pada etnis Melayu, etnis Jawa, etnis Tionghoa dan etnis India. Manfaat dari penelitian ini adalah memberikan informasi sebagai sumbangan yang bermanfaat bagi perumusan, implementasi serta perubahan kebijakan dan menganalisis persepsi serta isu-isu ekonomi dan juga dalam bidang politik yang mempunyai pengaruh besar, dan dapat pula diteruskan sebagai pengalaman-pengalaman yang terjadi dalam kelompok etnis, kehidupan, ras dan kelas sosial. Dan untuk peneliti selanjutnya sebagai bahan rekomendasi, begitupun hal yang dalam menunjang kelancaran proses pembangunan ataupun pada saat menghadapi masalah usaha, dan menjelaskan kepada masyarakat mengenai makna kewirausahaan pada etnis Melayu, etnis Jawa, etnis Tionghoa dan etnis India.

\section{METODE PENELITIAN}

Menurut Sugiyono

(2013),

penelitian kualitatif berlandaskan pada filsafat postpositivisme, karena digunakan untuk meneliti pada kondisi objek yang alamiah, (sebagai lawannya eksperimen) dimana peneliti adalah sebagai instrumen kunci, pengambilan sampel sumber data dilakukan secara purposive dan snowball, teknik pengumpulan dengan trianggulasi (gabungan), analisis data bersifat induktif atau kualitatif, dan hasil penelitian kualitatif lebih menekankan makna dari pada generalisasi.

Pada penelitian ini, teknik pengambilan sampel yang digunakan adalah teknik purposive sampling, "yaitu teknik pengambilan sampel sumber data dengan pertimbangan dan tujuan tertentu," (Sugiyono, 2013). Pertimbangannya adalah subjek atau informan yang diambil benarbenar menguasai tentang hal yang diteliti, mempunyai waktu luang, dan bersedia menjadi informan. Karakteristik sampel dalam penelitian ini adalah wirausahawan di kota Medan yang berwirausaha sebagai pedagang pakaian jadi. Sampel yang digunakan dalam penelitian ini yaitu sebanyak 8 orang.

"Observasi kualitatif adalah metode pengumpulan data yang dilakukan dengan cara mengamati dan mencatat secara sistematik gejala-gejala yang diselidiki", (Suharsimi, Suhardjono, \& Supardi, 2006). Didalam observasi dapat 
dilakukan dengan tes, angket, rekaman gambar, dan rekaman suara. Menurut Sudaryono, dkk (2013), menyatakan bahwa dalam penelitian kualitatif, pedoman observasi hanya berupa garisgaris besar atau butir-butir umum kegiatan yang akan diobservasi.

Menurut Nazir (1983), mendefenisikan wawancara sebagai proses memperoleh keterangan untuk tujuan penelitian dengan cara tanya jawab sambil bertatap muka antara si penanya atau pewawancara dengan si penjawab atau responden dengan menggunakan alat yang dinamakan interview guide (panduan wawancara). Oleh karena menulis hasil wawancara memiliki banyak kelemahan, maka selama melakukan wawancara, sebaiknya menggunakan instrumen pembantu alat perekam (tape recorder). Metode pengumpulan data dalam penelitian fonomenologi berfokus pada interview mendalam atau in depth interviews dan narasi atau narrative sebagai metodemetode kunci untuk membuat deskripsi dari pengalaman-pengalaman yang dilalui dalam hidup, (Bloor \& Wood, 2006). Kegiatan pengumpulan data yang utama pada penelitian fenomenologi adalah wawancara mendalam atau wawancara kualitatif. Karena dengan metode inilah esensi dari fenomena yang diamati dapat diceritakan dari sudut pandang orang pertama (orang yang mengalaminya langsung) menurut Creswell (2007), teknik pengumpulan data dalam penelitian fenomenologi adalah (a) wawancara; (b) refleksi diri; dan (c) gambaran realitas di luar konteks penelitian.

Dalam penelitian ini terdapat 2 tahap penelitian, yaitu tahap persiapan penelitian dengan menyiapkan paradigma tentang penelitian yang ingin diteliti.

Setelah menyiapkan paradigma penelitian, peneliti membuat pedoman wawancara. Pedoman wawancara berisi tentang pertanyaan-pertanyaan berdasarkan aspek dari penelitian yang akan ditanyakan kepada subjek. Selanjutnya, peneliti mencari subjek yang sesuai dengan karakteristik subjek penelitian. Untuk itu, sebelum wawancara dilaksanakan peneliti bertanya kepada subjek tentang kesiapannya untuk diwawancarai.

Pada tahap pelaksanaan penelitian peneliti harus membuat kesepakatan dengan subjek mengenai waktu dan tempat yang akan dilaksakan wawancara berdasarkan pedoman wawancara yang sudah dibuat sebelumnya.

Dalam penelitian kualitatif yang menguji validitas dan reliabilitas itu adalah diri peneliti sendiri, karena langsung juga sebagai human instrument. Hal ini seperti dinyatakan oleh Sugiyono (2013) bahwa validasi peneliti sebagai instrumen penelitian itu meliputi: evaluasi diri tentang kedalaman pemahaman metode penelitian kualitatif, penguasaan teori dan wawasn masalah yang sedang diteliti, kesiapan dan bekal memasuki lapangan.

\section{HASIL DAN PEMBAHASAN}

Penelitian ini menggunakan 8 (delapan) orang sebagai sumber data utama, kedelapan subjek ini dipilih menggunakan teknik "purposive sampling”, subjek yang dipilih memiliki karakteristik berupa wirausaha di kota Medan, sebagai wirausaha dalam bentuk pakaian jadi. Teknik ini digunakan agar sampel yang dijadikan subjek penelitian 
sesuai dengan kriteria dan tujuan dari penelitian ini, penelitian ini juga menggunakan metode wawancara semistruktur, yaitu peneliti mengajukan pertanyaan yang telah disediakan sebelumnya untuk di tanyakan kepada subjek.

Berdasarkan dengan hasil penelitian yang didapatkan dari etnis Tionghoa, pada subjek pertama memiliki beberapa sikap dalam berwirausaha seperti sikap hemat, kemandirian, tekun, solidaritas keluarga, keberanian, kepercayaan, kejujuran, kesabaran, adanya perhatian, sikap yang sabar serta memiliki sopan santun dalam bersikap serta fokus dan teliti. Subjek kedua menunjukkan bagaimana bersikap yang baik kepada pelanggan, subjek menjelaskan bagaimana sikap yang baik sebagai wirausaha, memiliki sikap dapat dipercaya, adanya perhatian, sopan santun, tekun, pentingnya pendidikan, fokus serta kestabilan emosi dalam menjalankan usaha.

Berdasarkan hasil penelitian yang didapatkan dari etnis Jawa, bahwa pada subjek ketiga memiliki beberapa sikap dalam berwirausaha seperti, etos kerja yang kuat, menghidari konflik, menerima segala sesuatu dengan tulus (nrimo/nrima), memprioritaskan kekerabatan (tuna satak bathi sanak), memandang pekerjaan mereka sebagai cara untuk mendapatkan berkah (laku tirakat), serta memberi maksimal upaya dalam melakukan pekerjaan mereka (panggautan gelaring pambudi). Serta pada subjek keempat, menunjukkan bahwa memiliki sikap dalam berwirausaha, serta dalam menjelaskannya dengan sangat detail dan jelas.
Berdasarkan hasil penelitian yang didapatkan dari etnis India, bahwa pada subjek kelima memiliki beberapa sikap dalam berwirausaha seperti, motivasi berprestasi dan ketaatan beribadah. Serta pada subjek keenam juga, menujukkan bahwa memiliki sikap dalam berwirausaha yang sangat jelas dan juga dengan sangat teliti.

Berdasarkan hasil penelitian yang didapatkan dari etnis Melayu, bahwa pada subjek yang ketujuh memiliki beberapa sikap dalam berwirausaha seperti memiliki bakat dan mental berwirausaha, optimis, toleran, berpegang pada adatistiadat, adanya sopan santun, ramah, demokratis serta mengutamakan diplomasi daripada kekerasan. Pada subjek kedelapan juga menunjukkan sikap yang baik dalam berwirausaha dan juga sangat detail dalam menjelaskannya.

Berdasarkan dengan pembahasan diatas, dapat dilihat dengan jelas makna kewirausahaan dari setiap etnis dalam berwirausaha. Bagaimana cara menghadapi persaingan pasar, mengelola keuangan, menjalin relasi, menghindari konflik, keikhlasan, kejujuran, motivasi berprestasi, sampai hal dalam berdoa untuk usaha. Namun persamaan juga dapat dilihat dari setiap etnis diatas yakni semangat yang tinggi, pantang menyerah dan optimis dalam berwirausaha.

\section{SIMPULAN}

Berdasarkan dengan hasil penelitian yang telah dilakukan untuk mengetahui makna kewirausahaan pada masingmasing etnis yang berbeda, maka kesimpulan dari penelitian ini adalah:

Adanya perbedaan makna kewirausahaan pada tiap-tiap etnis, pada 
etnis Tionghoa terdapat makna kewirausahaan seperti adanya perhatian, fokus dapat dipercaya, kerja keras, berhemat, solidaritas keluarga, pendidikan, dan kebajikan atau moral etika, kestabilan emosi, ketelitian, keberanian, serta kejujuran. Pada etnis Jawa terdapat juga makna kewirausaan seperti etos kerja yang kuat, menghindari konflik, menerima segala sesuatu dengan tulus (yang disebut nrimo atau nrima), memprioritaskan kekerabatan (tuna satak bathi sanak), memandang pekerjaan mereka sebagai cara untuk mendapatkan berkah (laku tirakat), dan juga memberi maksimal upaya dalam melakukan pekerjaan mereka (panggautan gelaring pambudi). Pada etnis India juga terdapat makna kewirausahaan yaitu motivasi berprestasi dan ketaatan beribadah. Serta pada etnis Melayu juga terdapat makna kewirausahaan, seperti memiliki mental berwirausaha yang sudah menjadi bakat, gaya hidup yang optimis, toleran, serta tetap berpegang pada adat istiadat dimana adanya sopan santun, ramah, demokratis serta mengutamakan diplomasi daripada kekerasan.

Selain perbedaan, ada pula persamaannya, tiap-tiap etnis dalam memaknai kewirausahaan, yaitu melayani konsumen dengan ramah, sopan santun dan memiliki sikap dalam wirausaha yang optimis.

\section{DAFTAR PUSTAKA}

Andri, N., Ronauli, P. T., \& Riyanti, B. P. (2019). Psychological Capital and Business Success of Chinese, Minangnese, and Javanese Entrepreneurs. International Research Journal of Business Studies , 157-166.

Anggito, A., \& Setiawan, J. (2018). Metode Penelitian Kualitatif. Jawa Barat: CV Jejak.

Anggraini, J. (2017). Konstruksi Perempuan Dalam Budaya Melayu (Studi Terhadap Perempuan Pengusaha UKM di Kota Palembang :
Pendekatan Ekonomi dan Agama). Jurnal Kajian Gender dan Anak, 199-214.

Bloor, M., \& Wood, F. (2006). Keywords in Qualitative Methods: A Vocalbulary of Research Concepts. London: SAGE.

Creswell, J. W. (2007). Qualitative Inquiry $\mathcal{E}$ Research Design: Choosing Among Five Approaches. 2nd Edition. California: Sage.

Edi, F. R. (2016). Teori Wawancara Psikodiagnostik. Yogyakarta: LeutikaPrio.

Endra, F. (2017). Pedoman Metodologi Penelitian (Statistika Praktis). Taman Sidoarjo: Zifatama Jawara.

Farid, M. (2018). Fenomenologi Dalam Penelitian Ilmu Sosial. Jakarta: Prenadamedia Group.

Fitrah, M., \& Luthfiyah. (2017). Metodologi Penelitian; Penelitian Kualitatif, Tindakan Kelas \& Studi Kasus. Jawa Barat: CV Jejak.

Hasbullah, \& Jamaluddin. (2013). Entrepreneurship Kaum Perempuan Melayu (Studi Terhadap Perempuan Pengrajin Songket di Bukit Batu Kabupaten Bengkalis). Jurnal Sosial Budaya , 1-13.

Hermawan, I. (2019). Metodologi Penelitian Pendidikan Kuantitatif, Kualitatif, dan Mixed Methode. Kuningan: Hidayatul Quran Kuningan.

Junaidi, H. (2016). Budaya Kerja Melayu Dalam Mengembangkan Wirausaha Mahasiswa di Perguruan Tinggi Kota Palembang. Jurnal Intizar , 95-111.

Koning, J. (2007). Chineseness and Chinese Indonesian Business Practices: A Generational and Discursive Enquiry. Journal East Asia , 129-152.

Lubis, Z. B. (2005). Kajian Awal tentang Komunitas Tamil dan Punjabi di Medan. Jurnal Antropologi Sosial Budaya ETNOVISI , 1-16.

Mariani, S., \& Eliana, S. (2012). Perbedaan Motivasi Berprestasi pada India Tamil dan India Punjabi di Kota Medan. Jurnal Predicara , 110.

Martawijaya, M. A. (2016). Model Pembelajaran Berbasis Kearifan Lokal : Untuk Meningkatkan Karakter dan Ketuntasan Belajar. Makasar: CV Masagena.

Putri, H. (2017). Analisis Perbedaan Sikap Kewirausahaan Antara Suku Jawa dan Suku Madura Di Wilayah Surabaya Selatan. Jurnal Bisnis, Managemen \& Perbankan , 1-84.

Sapir, P., Wasiti, H., \& Hermawan, A. (2014). Model Pembelajaran Kewirausahaan Berbasih Kearifan Lokal Untuk Penguatan Ekonomi. Jurnal Pendidikan dan Pembelajaran, 80-91. 
Soegoto, E. S. (2010). Entrepreneurship Menjadi Pebisnis Ulung (Edisi Revisi). Jakarta: PT Elex Media Komputindo.

Sudaryono, d. (2013). Pengembangan Instrumen Penelitian Pendidikan. Yogyakarta: Graha Ilmu.

Sugiyono. (2013). Metode Penelitian Pendidikan Pendekatan Kualitatif, Kuantitatif, dan RED. Bandung: Alfabeta.

Suharsimi, A., Suhardjono, \& Supardi. (2006). Penelitian Tindakan Kelas. Jakarta: Bumi Aksara.

Susanto, O., \& Nurrachman, N. (2018). Makna Kewirausahaan Pada Etnis Jawa, Minang, dan Tionghoa : Sebuah Studi Representasi Sosial. Jurnal Psikologi Ulayat, 86-108.

Suwendra, I. W. (2018). Metodologi Penelitian Kualitatif dalam Ilmu Sosial, Pendidikan, Kebudayaan dan Keagamaan. Bali: Nilacakra.

Tan, F. B. (2013). Global Diffusion and Adopion of Technologies for Knowledge and Information Sharing. United States of America: IGI Global.

Tandelilin, E. (2020). Entrepreneurial Values of Indonesian Chinese and Javanese on Micro and Small Enterprises. Journal Advances in Economics, Bussines, and Management Research , 251-255.

Wjaya, H. (2018). Analisis Data Kualitatif Ilmu Pendidikan Teologi. Makassar: Sekolah Tinggi Teologi Jaffray. 